\title{
ANALYSIS OF THE CONNECTIONS BETWEEN LAW AND MORALS, BETWEEN CUSTOMS AND CONTEMPORANEITY
}

\author{
Marțian Iovan* \\ "Vasile Goldiș" Western University of Arad, Romania, E-mail: iovanm@uvvg.ro
}

(Received: March 2020; Accepted: May 2020; Published: June 2020)

\begin{abstract}
This paper analyses the concepts of three great Romanian thinkers -theoreticians and philosophers of law - on the relations between law, morals and manners in order to discover, based on their idea filiation in the juridical Romanian culture, the differences of method and contents between them, to identify the practical implication in the field of performing the justice and law-making. Being trained and positioned in the core of the European juridical culture of their time, they reviewed the relations between law and morals, in a rationalist and humanist way, substantiating the need for the law to follow morals, the ethical principles both historically, and practically, the law-making being comprised as well. Thus, they leave room to the expression of human's basic rights and freedoms in a democratic judicial order, while the rules of law subordinating the morals and manner proved to be widely open to totalitarianism.
\end{abstract}

Keywords: morals, law systems, Xenopol, Speranția, democracy, the idea of justice.

\section{Introduction}

Some great Romanian philosophers of law concepts on the concept connotations and relations between law, morals and manner are reviewed in this paper, in order to emphasize as strongly as possible the theoretical and practical implications both in the development of the sciences of law and in perfecting the law-making.

Research, analyses of the connections between law and morals appeared since ancient times and were carried out again with a tight intensity up to our times. Plato claimed that the order of Polis, the observance of the laws and principles of justice are conditioned by the individuals' virtues such as wisdom, courage and modesty. However, these are related to the field of morals. The rules of morals and justice condition each other, being equivalent to the platonic concept. The interests of this kind continued in Aristotle's, Christian, Middle Ages, Modern philosophers' works up to these days. Some tried to claim the priority of the law towards morals,

\footnotetext{
* Corresponding author: Marțian Iovan.E-mail: iovanm@uvvg.ro
} Commons - Attribution 4.0 International - CC BY 4.0) which permits unrestricted use, distribution, and reproduction in any medium, provided the original author and source are credited. 
Iovan, M., (2020)

respectively in relation to people's inside life -which was transposed in law-making, thus leading to a totalitarian State, rule of law that suffocated more or less the individual's personality. Others claimed for the need to balance relations between various forms of law and morals, while others declared the leading role of the moral principles and values in law-making and functioning of the public institutions. How, these connections between law and morals were thought of, had implications overtime on the Polis organization, in the evolution of the rule of law and of citizen's status in the society. Corresponding to each conception contents and nature regarding the relation between law and morals, there resulted in various law-making types, rules of law ranging between totalitarian State and state of law, between dictatorship and democracy.

According to the logic, there are to be reviewed the concepts of some brilliant philosophers of law who were experts not only in the sciences of law but also had multidisciplinary and multicultural training. They were educated in the most renowned universities in Romania and in the Western of Europe. Benefiting of deep knowledge of the history of universal philosophy, and of European one - basically, of the history of juridical ideas, been skilled in the capacity of cross- and metadisciplinary research and competent in using truth discovery measures specific for social sciences - these philosophers and also scientists are A.D. Xenopol, M. Djuvara and E. Speranția. Their work belongs to a filiation of European ideas circumscribed to humanity and rationality, being a product of their democratic attitudes and beliefs.

\section{Alexandru Dimitrie Xenopol: law follows the manners [1]}

After graduating the academic studies in philosophy and juridical sciences, the European scholar - A.D. Xenopol $(1847$ - 1920) - carried out scientific research activity in several branches of the knowledge: economics, history, philosophy of law and culture, anthropology, people's psychology, sociology, general theory of history, the science of the evolution etc. His ideas on law and its connections with other cultural fields are presented with persuasive arguments in the work "Cultura națională" (National Culture), published in 1868 [2].

The Moldavian scholar analyses the law from an evolutionist and cross-disciplinary perspective, in this regard, capitalizing his huge scientific and universal culture and his brilliant creative sense. The law is considered as a basic part of people's culture together with the manners, the language, the folk art, and the beaux-arts etc., having to regulate the nation's individuals' relations between them and between some groups and others, thus contributing in preserving and developing the national being [3]. During history, the law evolved in tight connections with the manners, the customs, not being anything else than an externally visible projection of people's soul universe.

58 sciendo Journal of Legal Studies Volume 25 Issue 39/2020 ISSN 2457-9017; Online ISSN 2392-7054. 
The causes for the origin and development of the law may be found in human nature's social needs, among which some are triggered by the human's quality as a person, namely of being able to impose its will on the surrounding world and in relations with its kind. In a community, the persons' wills may trigger conflicts, animosities which might endanger the social order and peace. This is why, inside the human group, there appeared the need for the idea of law in order to set the limits between which the individuals may exert their will freely. Other causes result from human's nature as a social being, from living in harmony with the fellows. Here, there intervene feelings, senses actions, causing the people to get closer to each other, to cooperate in a more solidary community which is united in front of the inside, and outside dangers. The common life, people's social feelings generated the manners. From the organic twinning, a combination of the two qualities of human nature that of a person with a will, and that of social being (homo socius) - holder of numerous feelings and livings - the tight connections between law and morals originate.

The same interpersonal relations may fall either under the law regulating action or under that of the manners. The manners express feelings and affective living bringing the people together to cooperate, to reinforce the solidarity, or to mutually assist each other. On the other hand, the law regulates the interpersonal relations caused by their will. It results from here that the difference between law and manners resides in that the manners rely on feelings in time while the law is the result of the need to regulate individual wills and the idea of law in order to keep and preserve the social peace. The connections between law and manners are obvious both when manners reach the situation of being regulated by the juridical norms, and also the opposite, when the law is influenced, shaped by the manners action [4]. Basically, Xenopol claims, "what unites the law with the manners is that both originate from the relations between individuals; what separates them is that the relations originating the law are caused by will, while those from manners arise from senses" [5]. By the way of combining people's will with their feeling, differentiations result between the systems of juridical norms and people's manners, they having historical and national specificity everywhere.

As each people, each nation has its unique special life and history, and each nation's soul is unique, it results that also their products - among which both manners and law - have specific particularities. However, as the mankind's soul is formed of common general elements, valid for all nations, it results that manners and law evolution have a historical trend towards sameness, reinforcement of the common elements for all peoples, but without ever reaching to the atrophy of the cultural forms of national specificity, including the law and manners. Xenopol exemplifies and substantiates the validity of these ideas looking to discover certain dominant notes in the national soul of some European peoples and on other continents. These 
Iovan, M., (2020)

"general directions" of the national spirit cause the manners and law character. In addition, they highlight the different ways of reception of Roman law in various areas of Europe. Xenopol claims that we can conclude that the law may be treated as a field of the national culture from such premises. We can also deduct that the law, in its historical evolution and development, follows the morals, meaning that "the law must observe the morals" [6]. The practical conclusion is that law-making, codifying the juridical norms by the specialized and legitimate bodies of the State must be an expression and extension of the manners, of the feelings uniting people's individuals, or to be a resultant of the "people developed law."

Consequently, drafting laws, new juridical rules should not occur by accident, or by copying other people's law, nor to imitate the foreigners' law, without considering the basis: after all, we talk about people's souls. "For the law and manners live and develop - emphasized Xenopol, they have to be exerted by the people originating them" [7]. Thus, the juridical forms published by the State specialized bodies are to be fully compliant with the basis which they have to arrange in order to achieve the idea of justice.

Influenced by the main schools of juridical philosophical thinking of the $19^{\text {th }}$ century Europe, especially by the main German and French philosophy of law, the concept and conclusions reached by Xenopol on the connections between manners and law in their historical evolution were proved with sufficient argument taken from the social sciences and humanities, from history, sociology, anthropology, people's psychology, general economy, in particular, thus preserving their validity up to our days. The vast and profound Xenopol's juridical culture deeply influenced his research during maturity, generating his fundamental works with which he contributes to the development of the European scientific and cultural heritage, exerting a beneficent influence not only on the development of the culture and spirituality but, mostly on the practices of taking a major political decision, of reforming and perfecting the law systems up to our days.

\section{Law and Morals in Mircea Djuvara, Romanian Scholar's [8] Thinking}

Mircea Djuvara (1886-1944) analyzed philosophically the connections between the various types of norms regulating people's activities, such as the juridical norms, the moral norms, the technical precepts of decency and religion. Each of them exercises regulating functions in a field of social relation, has a specificity, differentiating themselves from the other, but they also have a common basis by which they resemble. The main subject of Romanian scholar's interest was the analysis of the complex relations between law and morals and customs. The scope of morals and law form a whole - highlighted Djuvara - where the moral and juridical realities may be regarded as ethical-juridical reality and, in a wider meaning, an ethical

60 sciendo Journal of Legal Studies Volume 25 Issue 39/2020 ISSN 2457-9017; Online ISSN 2392-7054.

Web: publicatii.uvvg.ro/index.php/jls. Pages $57-68$ 
reality. So understood, it results in the conclusion that the entire evolution of the system of norms in the society is directed and governed by the moral norms.

The basic common elements for law and morals are many, but the main one consists in the fact that the component norms of each field are logical and rational. In this context, Djuvara claims that "both in law and in morals, the appreciation applied to the status quo is a rational one and not plain acknowledgment reasoning"[9]. This rational appreciation comprises the idea of obligation which is strongly expressed in law and more reduced in morals. The edifice of the entire system of law relies on the idea of obligation. Therefore, the juridical obligations are different from the moral ones, just like the rights corresponding to these types of obligations. These rational ideas must be understood in tight connection with the ideas of freedom, justice, wellness and moral perfection without which there cannot be naturally either law or morals - emphasizes Djuvara.

The concept of obligation is abstract, general, always the same regardless of the place and time, just like the notions of geometry, even if they apply to some extremely diverse moral and juridical realities. The intent played a required and unconditional part in the historical evolution of law, being an element of the moral reality. As the law developed, the more its intentional content played a higher role in satisfying social needs. The historical development of the law shows that morals and law progressively harmonized each other in the way that the juridical facts were more and more dependent on the moral realities; the immoral deeds not being protected by law "as the law relies entirely on the idea of morals"[10]. That is why, when the practice of law collides with morals (which may happen sometimes) judicial errors occur. They have to be rectified by streamlining the wrong juridical norms by the law-making body, magistrates or other state bodies entitled to adopt norms in their field, where applicable.

As for the differences between the law and morals, they reside in each of their subjects: morals have as subject the regulation of the internal deeds, of those belonging to the scope of person's intents; the law has as subject the regulation of the external deeds, material actions done by persons which represent an extension of the intentions to the exterior of the interior life of the persons in connection with other individuals. This way, the law consecrates the person's moral freedom which, in principle, targets his/her own moral ideals. The juridical reality, implicitly the parties' intentions and will, is logical and rational.

Another difference between law and morals consists of that obligation towards you may occur in morals, which there is no such thing in law. In law, the obligations incur towards other persons, while, in morals, the person's obligation incurs to oneself derives from the undertaken moral ideal, from the will of moral perfecting which has to be observed. It results from this difference another one at the level of sanctions application: sanctioning is applied in law, not in morals. As State organized 
Iovan, M., (2020)

force, the sanction cannot be applied to intents, to a person's interior life; only moral sanctions of social reprobation of the persons committing immoral deeds may be applied.

From the difference that the law deals with external deeds and the morals with the internal ones, it results another one: "moral legislation tends to simplification, the juridical legislation to the proliferation [11]." So it happens that, from one age to another, there are fewer rules in morals, while in law there are rules of several kinds and in continuous development.

The essential aspect synthesizing Djuvara's concept on the relations between law and morals is presented as follows: "All norms referring only to human's soul activity, to the activity of one's conscience, to one's intents, are therefore norms of morals, while those referring only to the material activity performed outside the persons in contact with other persons are norms of law" [12]. There are interesting the analyses performed by the Romanian scholar on other extra-juridical and extramoral norms such as the precepts of decency, the religious and technical norms. Though many authors comprise the precepts of decency in the scope of morals, Djuvara believes that these are fundamentally different both from the juridical and the moral norms are they are not imposed either rationally or logically. Such norms do not trigger rational obligations, the precepts of decency, the religious and technical norms are hypothetic, conditioned, unlike those of morals and law which are categorical and unconditioned of rational conduct.

Djuvara's concept of the relations between law and morals proved to be well substantiated, useful for the development of the sciences of law. Based on this concept, a precise distinction could be made between the subject of the study of ethics and that of the sciences of law. Considering the juridical practice, it had and always will have a role in perfecting the law-making activity, the regime for applying the juridical sanctions by the State organized force and the application of the rule of law principles.

\section{Law, Morals, and Manners in Eugeniu Speranția's Thinking}

The Transylvanian scholar Eugeniu Speranţia (1888 - 1972) [13] analyzed the relations between law, manners and morals from meta- and cross-disciplinary positions, capitalizing vast knowledge of the history of the philosophy of law, ethics, juridical sociology, psychology and juridical logics, history of law and morals. As a polyglot personality, he captured critically the innovative spirit and the ideas propagated by the main schools of critical thinking of his time. His writings in the field, especially the work named "Introduction to the Philosophy of Law" [14], influenced on the development of the juridical sciences of the last decades in Romania. 
Critically, relating himself to Rudolf von Ihering philosophical writings, the Transylvanian scholar takes the finalist explanation of the juridical order and law the one referring to their purposes and destinations. The law had a purpose to achieve at all times, and it will always have a mission to accomplish. The law is a rational and intended product, consisting of norms meant to regulate the individual conducts and to set a consistent society that results, implicitly, from the existence of sanctions, of coercion in what is social. The observance of the juridical norms is guaranteed by the establishment of a special body and some modalities/ fix procedures to apply the sanctions. The deviations from the juridical norms are sanctioned by institutionalized agents in the structure of the state which apply them according to consecrated formulas and in legally pre-established ways. As Speranția wrote, the manners "are mostly a collective irrational product and their social consecration and turning into permanence is a natural but not intended process" [15]. Even if the manners are followed by the implementation of some sanctions in case of people violating some non-juridical norms, they differentiate themselves from the juridical ones by the fact that they do not possess specialized agents, nor fix modalities of execution. Sanctioning the deviation from the manners (by scolding, public indignation, expressing in some way disagreement and critical detachment etc.) is achieved by anybody anyway. The community reacts diffuse, volatile and without benefitting of an institutionalized organ, so expressing an attitude of conformism, of respect for custom, imitation, without a rational explanation. Moreover, the law possesses in it a certain own strength, sort of an authority imposing on the consciences.

Sperantia makes a distinction between morals and manners also from another perspective considering that the "manners are social norms issued anonymously, spread by plain social contagion, submitted to the variations of the use and implying diffuse sanctions" [16] resulting in uniformity and relative solidarity of the individuals belonging to the social group, without intended following of such purposes. Unlike manners, morals consist of a total of rational, deductive norms with finality, being derived from rational motives and principles. Its imperatives are decreed by individuals' intimate persuasion. Even if not being a collective diffuse creation, the moral norms acquire collective consecration due to the group belief in the same religious and philosophical values.

Unlike manners that are observed by individuals for appraisal, positive appreciation or for avoiding the impeachment, the collective disapproval, the moral norms are governed by each individual's moral convictions and persuasions. These differences do not exclude the presence in the group of some deeply immoral persons but behaving according to the manners.

The historical evolution of the relation between morals and manners gave priority to the manner, Speranţia emphasized. The individual's moral conscience developed due to the social pressure; "it would be an interiorization of the collective 
Iovan, M., (2020)

Analysis of the connections between law and morals, between customs and contemporaneity

conscience" [17]. Reaching maturity, the individual's conscience is to be lesser influenced by exterior contingent factors, so being able to accomplish the role of the interior for which regulates the individual behavior. By this, the morals prove its rational and intended character, by this resembling to the law.

The customs or the "earth custom" places between the law and the manners, states the Transylvanian philosopher, as social prescriptions likely to the religious rituals. The customs are gradually settling down in the human community as habits, routine, "holy tradition" in such a way that the group would no longer accept breaches, substitutions of these social norms. Gradually, in their historical evolution, the customs turn into juridical norms, with intended finality and thus leave the scope of the manners.

According to the above, morals represent a rational system of norms for one's conduct, serving as a criterion for appreciating own behaviors, persuasions, and deeds, in guiding each individual's behavior according to the juridical order. The true warranty of the law, "the fundamental forces of the Law", underlines Speranția, "are its logical validity and its moral compulsiveness. All added beyond this, such as fear, force, or interest, are plain expedients with monotonous efficiency, sometimes very prompt and energetic, but without durability" [18]. Contrarily, in any act of injustice, the violation of the law norm involves an immoral act. But the violation of some moral principles is not always injustice, thus the deviation from the moral norm does not trigger the application of some juridical sanctions; the deed itself remains only under the enforcement of some moral sanctions.

If we accept that everything that is juridical has to be, at the same time, moral, then the law-making process, the process of drafting the new norms of law has to be submitted to the moral judgments and values. The law-maker could not distance itself from the morals, could not issue provisions for others if his conscience does not accept them for himself [19].

However, all along the history, systems of law, law orders appeared and comprised elements/ norms in contradiction with morals. Such articulations of the law opposite to the moral values - are among those drafted with flaws, are those juridical norms deviating from the fundamental principles of law and morals. They arose from the will of a social class interested in the domination, submission of other classes, the will of an oligarchic group, or from an ideology reluctant to the humanist values. Such denaturation of the juridical norms succeeded to darken the human reason and the true justice. In such historical situations, there was always required the change of the existing juridical order - actions caused either by the intervention with certain rectifications applied to the laws in contradiction with the morals, by reforms, and small repairs or by radical changes of the system of law, such as riots. The path to take, claims with arguments Speranția, is the legitimate change, the right revolution,

64 sciendo Journal of Legal Studies Volume 25 Issue 39/2020 ISSN 2457-9017; Online ISSN 2392-7054.

Web: publicatii.uvvg.ro/index.php/jls. Pages $57-68$ 
any justified way to restore the justice so that law and morals are brought in full compliance, and subordinated to a univocal purpose.

All of Speranția's ideas and demonstrations have profound scientific substantiation. The presented arguments are taken not only from the philosophy and sciences of the law but also from the social sciences and humanities, especially from history, sociology, social psychology, and anthropology. These qualities of the Romanian thinker's work made possible their fast integration in the European circuit of juridical ideas and culture. The viability of Speranţiawork until our times is explained both by its connection to the European philosophical-juridical values, and by its belonging to a national filiation of law philosophical ideas and principles opened in Romania by the representatives of the Transylvanian School starting with Samuil Micu, and continuing with Simion Bărnuțiu, Titu Maiorescu, Xenopol, Drăghicescu, Djuvara, and other remarkable humanist thinkers.

\section{Instead of conclusions}

Comparatively approaching the three concepts on the connections between law, morals and manners and their practical implications for the law-making process and the achievement of the justice in general, we may conclude that there is continuity between them and also there is differentiation regarding the style, amplitude, and depth of the approach. The three authors'analyses are guided by their intimate attachment to the great philosophical and juridical values of the European culture, to the rule of law principle and the democratic ideals based on the supremacy of the moral values compared to the juridical ones. The theoretical and practical conclusions they reached arose from their inspiration from the valuable traditions of the national culture, of the universal philosophy of the law, from the history of moral ideas, and, not last, from the works of some great European thinkers of their time. Basically, the three Romanian scientists' analyses have an original character and comprise apertures to the perfecting of the juridical practice in order to strengthen the democracy and to observe the founding principles of the rule of law. From the unanimous support of the idea on the primacy of the morals, of the manners, of the "law set by the people" related to the juridical norms to be drafted and further passed by the law-making body, it results in their deeply humanistic and democratic attitude. They did not accept to apply the theory, trending at that time, of the "void shapes" in the law-making, in restoring the justice, in achieving the rightfulness in the society. The imported juridical forms, those introduced by imitation, not resonating with people's lives, have no place in the law-making process and the functioning of the State. If there are contradictions between morals, manners, on one hand, and the juridical norms, on the other, certainly judicial errors, social tensions, various forms of social discontent will occur. In such situations, the interventions to rectify the faulty drafted laws, juridical norms in contradiction with the moral values become 
Iovan, M., (2020)

legitimate, and so the harmony between law and morals at the level of each social group, and in the law system overall is reinstated.

\section{Acknowledgments}

The author thanks the anonymous reviewers and editor for their valuable contribution.

\section{Funding}

This research received no specific grant from any funding agency in the public, commercial, or not - for - profit sectors.

\section{Author Contributions}

The entire article was written by Marțian Iovan.

\section{Disclosure Statement}

The author has not any competing financial, professional, or personal interests from other parties.

\section{References}

1. Djuvara, M., (1999). Teoria generală a dreptului. Drept rațional, izvoare și drept pozitiv(General Theory of the Law, Rational Law, Sources and Positive Law), ALL BECK, Bucharest.

2. Speranția , E., (1944). Introducere în filosofia dreptului (Introduction to the Philosophy of Law), second edition, reviewed and completed, Publishing House "Cartea românească of Cluj, Sibiu.

3. Xenopol, A.D., (1868). Cultura națională (National Culture), in Convorbiri literare, no. $10-17$.

4. Xenopol, A.D., (1999), Națiunea română (Romanian Nation), edition, introductive study and notes by Constantin Schifrineț, Bucharest, Editura Albatros.

\section{Notes}

[1] Xenopol's education was for a scientist, philosopher of history and law, as a great historian and genial man of culture, in the scientific and cultural Romania of the mid-19th century, and especially in the academic area, in the West European cultural life. He graduated two schools - of philosophy and of law - at the University of Berlin. His first doctoral degree in the science of law was awarded in 1871. The doctoral thesis was "De societatum publicanorum Romanorum historia ac natura iuridiciali", and was awarded Magna cum laude. The second doctoral degree was to be awarded in philosophy. Among others, he was concerned in his young years with the philosophy of law, interests concretized in studies of rare depth. In his adult years, he focused his research and creative efforts in the fields of history, philosophy of culture and sociology history, in political economics, acquiring wide scientific popularity not only in Europe but also on other continents. N. Iorga highlighted 
Iovan, M., (2020)

"Vasile Goldiş" Western University of Arad

Analysis of the connections between law and morals, between customs and contemporaneity

that"his works constitute itself as one of the greatest endeavors of the Romanian spirit applied to science". (See N. Iorga, "Neamul românesc", year XII, nr. 64, March 8, 1917).

[2] See A.D. Xenopol, "Cultura națională" (National Culture), in Convorbiri literare, no. $10-17,1868$.

[3] A.D. Xenopol, "Națiunea română" (Romanian Nation), edition, introductive study and notes by Constantin Schifrineț, Bucharest, Editura Albatros, 1999, p. 136.

[4] See cit. paper, p.112.

[5] Ibid., p.112.

[6] Ibid., p.119.

[7] Ibid., p.120.

[8] Mircea Djuvara was a representative personality of the philosophy and sciences of law in Romania in the first half of the 20th century, strongly integrated into the European scientific and cultural area, and also in the international circuit of the juridical idea. He graduated two faculties - of law and of letters and philosophy at the University of Bucharest. Possessing cross-disciplinary, philosophical and multicultural training, he took the position of a tenured professor at the Chair of the General Theory of Law, then he passed to the Chair of Encyclopaedia and philosophy of law at the Faculty of Law in Bucharest. In addition, he was a professor of law at the Academy of International Law of Hague, and an active member in numerous European institutions of juridical profile. Giorgio Del Vecchio saw him "as one of the great contemporary thinkers in the field of juridical philosophy", his works offering to the legal advisors' deep analyses of the juridical phenomena and a large horizon of thinking and knowledge.

[9] Djuvara, M., "Ce este dreptul" (What is the Law), in M. Djuvara, Teoria generală a dreptului. Drept rațional, izvoare și drept pozitiv (General Theory of the Law, Rational Law, Sources and Positive Law), ALL BECK, Bucharest, 1999, p.374.

[10] Djuvara, M. Teoria generală a dreptului. Drept raţional, izvoare și drept pozitiv (General Theory of the Law, Rational Law, Sources and Positive Law), ALL BECK, Bucharest, 1999, p.376.

[11] Djuvara, M., "Morala și dreptul. Asemănări și deosebiri” (Morals and Law. Similitudes and Differences), in cited work., pp.374-381.

[12] Djuvara, M., "Noțiuni preliminare despre drept" (Preliminary Notions of Law), in cited work, pp. 61-138.

[13] Eugeniu Speranția was a Romanian scientist who brought outstanding creative contributions in the development of the philosophy of law, logic, and juridical sociology, in the history of juridical ideas. After graduating from the faculties of philosophy and law at the University of Bucharest, he took intensive specialization studies at the University of Berlin, further choosing for an academic career. During 1934 - 1949, he worked as a professor at the Chair of Philosophy of Law at the University of Cluj. His monographs, studies and academic treaties are deeply integrated, historically, logically and from an information point of view, in the national and European juridical philosophical culture of his time, conferring it new elements of brilliance by his creations.

[14] See Speranția , E., "Introducere în filosofia dreptului" (Introduction to the Philosophy of Law), second edition, reviewed and completed, Publishing House "Cartea românească of Cluj, Sibiu, 1944. 
Iovan, M., (2020)

Analysis of the connections between law and morals, between customs and contemporaneity

[15] Speranția, E., "Introducere...", p.351.

[16] Speranția, E., "Drept, moravuri și morală", (Law, Manners, and Morals) in cited work, pp.349-365.

[17] Ibid., p.353.

[18] Ibid., p.359.

[19] See cit. paper, p360. 